\title{
Methodology and impact categories of environmental life cycle assessment in geothermal energy sector
}

\author{
Michat Kaczmarczyk ${ }^{1, *}$ \\ ${ }^{1}$ AGH University of Science and Technology, Faculty of Geology, Geophysics and Environmental \\ Protection, Department of Fossil Fuels, 30-059 Krakow, Poland
}

\begin{abstract}
The development of renewable energy sources, including geothermal energy, causes that more and more attention should be devoted to their environmental impact in a holistic approach. Currently, the impact of geothermal installations on the environment is analyzed in the context of emissions of pollutants into the atmosphere at the operational stage. Additionally, sustainable development and creating a responsible energy mix requires the use of tools that will provide precise information about the effectiveness of the proposed technological solutions and their impact on the environment. The LCA lifecycle assessment can be such a tool. The complexity of the investment process, which is the construction of a heating plant, a combined heat and power plant or power plant based on geothermal energy, results mainly from changing geological, topographical and environmental conditions. In such a case, the precise determination of the methodology and the definition of impact categories are crucial. The article is a review of the applied methodologies in the world, taking into account impact categories and databases used in conducting the LCA in the geothermal energy sector.
\end{abstract}

\section{Introduction}

Sustainable development that respects the environment, requires a responsible approach to creating an optimal energy mix. Natural elements of that mix are currently renewable energy sources which percentage share in energy production is systematically increasing. Therefore, there is a situation where a wider view of renewable energy sources and its impact on the environment becomes a necessity. Geothermal energy, being a renewable energy source, is perceived as almost completely emission-free during working time [1]. In terms of emission of combustion products into the atmosphere, this is a correct approach, but in order to determine the real impact on the environment, the proper way is the implementation of life cycle assessment (LCA) to geothermal energy sector.

The main categories (Fig. 1) that need to be defined at the stage of lifecycle assessment include land use, geological threats, emissions to the atmosphere, emissions to water,

\footnotetext{
* Corresponding author: $\underline{\text { mkz@agh.edu.pl }}$
} 
emissions to rock mass, water consumption, impact on biodiversity, noise and light emissions, and waste heat $[2,3]$. The scale of the undertaking which is the life cycle assessment, taking into account the above information, requires a great interdisciplinary and consideration of each case in an individual and as precise a manner as possible.

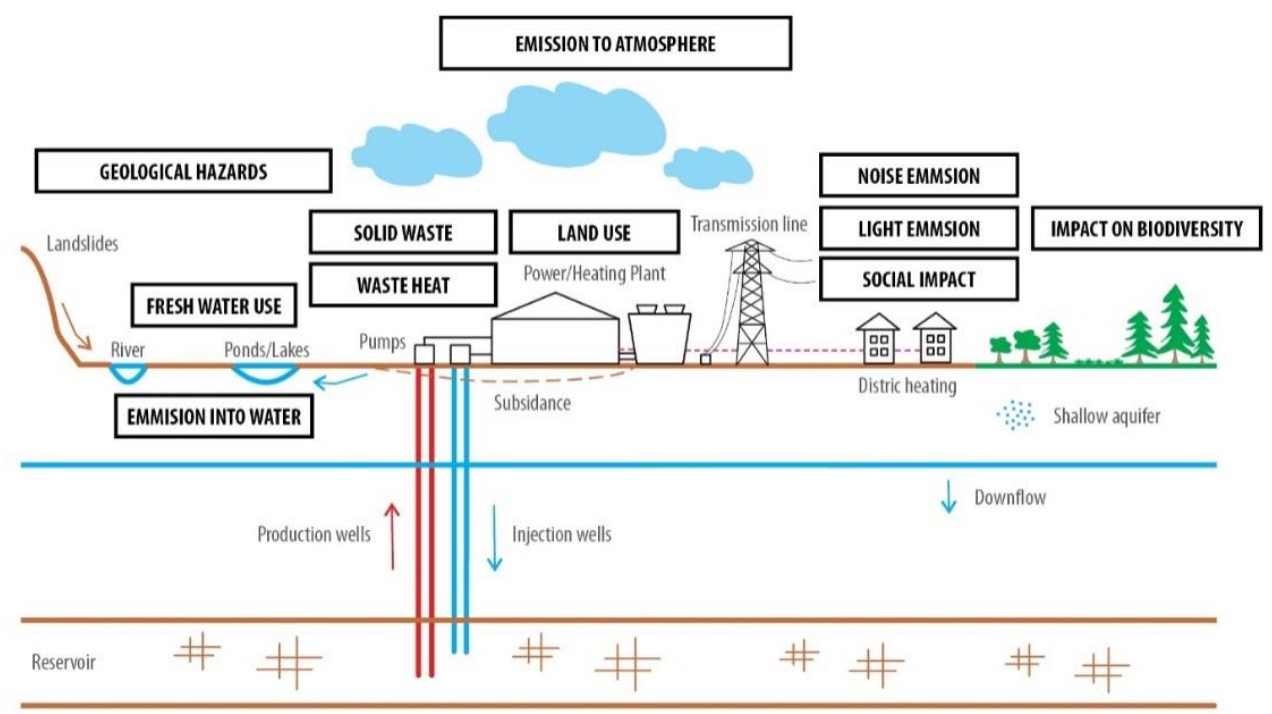

Fig. 1. Environmental impact of geothermal power plant/district heating (based on $[3,4]-$ modified).

\section{Life Cycle Assessment methodology}

Life cycle assessment is a standardized method of conduct for the analysis of environmental hazards associated with the product/process throughout its lifetime. The principles and structure of the LCA are defined in the PN-EN ISO 14040 standard "Environmental management. Life cycle assessment. Principles and framework" [5], while the requirements and guidelines for conducting LCA are contained in the PN-EN ISO 14044 standard "Environmental management. Life cycle assessment. Requirements and guidelines" [6]. Additionally, standards PKN-ISO/TR 14047 "Environmental management. Life cycle impact assessment. Examples of applications of ISO 14042", ISO/TS 14048 "Environmental management. Life cycle assessment. Data documentation format" [8] and PN-EN ISO 14001" Environmental management systems. Requirements with guidance for use" [9] are helpful in the development of LCA.

LCA allows to proper assessment of all environmental aspects at the stage of extraction and processing of mineral resources, production, distribution, operation, recycling and final disposal of waste [10-13]. For the basic tasks resulting from the implementation of the LCA, it is important to consider the documentation of the impact of the product/process on the environment at every stage of its life and to analyze the possibility of interrelated environmental impacts resulting from the product/process improvement.

The first stage of the LCA is to determine the purpose and scope of the research. At this stage, it is important to justify why life cycle assessment is carried out, which will determine the level of detail that it will be performed. To make this possible, it is necessary to define the product system and functional unit. Product system is defined as a set of material and energetically connected unit processes [14]. The functional unit is defined as the quantitative 
effect of the product system (the reference unit) in the LCA [5]. In the considered case of geothermal energy, the scope of the research should be the environmental impact of the electricity/heat production, while the functional unit should constitute as a unit of electricity - i.e. MWe, or heat - i.e. TJ. The next step in the LCA is to determine the set of inputs and outputs (LCI, life cycle inventory), on the input side - raw materials and energy, on the output side - products, waste and emissions to the environment. This stage, in which the product is creating, determines the boundaries of the system. Life cycle impact analysis (LCIA) is the third stage. It consists of assigning particular items in the developed catalog of input and output data of relevant impact categories, which allows for a reliable assessment of the environmental impact for the analyzed product/process. The last stage is the interpretation of the results. This stage should be considered as the most difficult and the riskiest for error.

Despite the normalization of the LCA method by the applicable ISO standards, it is important to calculate indicators for individual impact categories. For this purpose, various methods are used (Tab. 1), of which in the context of application to renewable energy sources, including geothermal energy, the following should be mentioned: Eco-indicator, CML, ILCD, Monte Carlo and ReCiPE. In the case of geothermal energy, the analyses performed so far [15-25], all methods except ReCiPE were used. Each of these methods is an attempt to resolve two major problems - difficulty of interpreting the obtained results in a comprehensive approach and the diligence of collecting all necessary environmental data.

In summary, the mandatory elements during LCA implementation are: selection of impact categories, category indicators and characterization models, LCI results assignment (classification) and calculation of the category index value (characterization). The optional elements are: calculation of the category index value relative to reference information (normalization), grouping, weighing and data quality analysis.

\section{Database and impact categories}

Conducting LCA remains rare in geothermal energy. The vast majority of publications concern geothermal power plants $[3,4,15,17,19,20,22-25]$. From the point of view of the usefulness of the current experience from the use of the LCA method in heat engineering using geothermal energy, the publications Nitkiewicz and Sekret [18] and Bartolozzi et al. [21] could be helpful. They do not analyze geothermal heat plants, but the definition of a functional unit or analysis of a heating network could be useful. In the case of the functional unit, it is clear that most mentioned researchers used kWh. Only Nitkiewicz and Sekret [18] defined functional unit as the total amount of heat that should be delivered to customers connected to the heating network.

Considering the above, any guidelines resulting from world experience in the development of LCA for geothermal energy should be seen in publications on renewable energy sources or conventional systems. It is due to the fact that certain aspects of LCA for geothermal district heating and geothermal power plants have characteristics in common with the generally perceived energy industry. In addition, in the context of the assessment of district heating systems, the geothermal energy production sector, to which the above mentioned publications relate, may constitute a significant complement to knowledge for district heating. 
Table 1. Short description of LCA methods.

\begin{tabular}{|c|c|c|}
\hline Method & Description & Used by \\
\hline $\begin{array}{l}\text { Eco- } \\
\text { indicator } \\
99\end{array}$ & $\begin{array}{l}\text { Significant emphasis is placed on the assessment of damage. The } \\
\text { LCA method in this approach has been extended to the weighing } \\
\text { method. It allows calculating a single result for the total } \\
\text { environmental impact. The method includes the assessment of } \\
\text { three groups of impact categories: human health (number and } \\
\text { duration of diseases, life years lost due to premature death), } \\
\text { ecosystem quality (species diversity) and resource consumption } \\
\text { (surplus energy needed in the future to extract lower quality } \\
\text { mineral and fossil resources) [26]. }\end{array}$ & $\begin{array}{c}\text { Nitkiewicz and } \\
\text { Sekret (2014) }\end{array}$ \\
\hline CML & $\begin{array}{l}\text { CML allows characterizing the coefficients in order to quantify } \\
\text { the share of impact categories and normalization factors. The } \\
\text { method limits quantitative modeling to the early stages of the } \\
\text { cause-and-effect chain to reduce uncertainty as much as possible. } \\
\text { The results are grouped into categories of midpoints according to } \\
\text { common mechanisms (i.e. climate change) or commonly accepted } \\
\text { groups (i.e. ecotoxicity). The normalization rates are calculated on } \\
\text { the basis of total substance emissions and characterizing factors } \\
\text { per substance [27]. }\end{array}$ & $\begin{array}{l}\text { Buonocore et } \\
\text { al. (2015) }\end{array}$ \\
\hline ILCD & $\begin{array}{l}\text { Method of midpoints recommended by the European Commission, } \\
\text { which complies with the applicable PN-EN ISO } 14040 \text { and PN- } \\
\text { EN ISO } 14044 \text { standards. The ISO standard is an important } \\
\text { framework for LCA, however these frameworks leave a number of } \\
\text { important choices. These choices may affect the credibility and } \\
\text { comparability of the LCA results. The method was developed to } \\
\text { provide guidelines to increase the consistency of the methodology } \\
\text { and to ensure the quality of the results obtained [28]. }\end{array}$ & $\begin{array}{l}\text { Pratiwi et al. } \\
\text { (2018), } \\
\text { Bartolozzi et al. } \\
\text { (2017) }\end{array}$ \\
\hline $\begin{array}{l}\text { Monte } \\
\text { Carlo }\end{array}$ & $\begin{array}{l}\text { Simulation based on modeling systems, the course of which } \\
\text { depends on random factors. The method assumes that all analyzed } \\
\text { data are to some extent uncertain. This is particularly true when } \\
\text { LCA is performed for the comparison of two products. In practice, } \\
\text { simulation based on the assumption of random values for each } \\
\text { uncertain input. The procedure is repeated many times, and its } \\
\text { results are recorded, creating a distribution of uncertainty for the } \\
\text { final result }[19,22] \text {. }\end{array}$ & $\begin{array}{l}\text { Buonocore et } \\
\text { al. (2015); } \\
\text { Hanbury and } \\
\text { Vasquez (2017) }\end{array}$ \\
\hline
\end{tabular}

In general, the issues of databases and impact category are related to the specific methodology used. However, this is not a rule. The most popular databases are: Ecoinvent, Probas, Agri-BALYSE, Blue Mountain, JRC's European Reference Life Cycle Data System (ELCD), NREL's U.S. Life-Cycle Inventory Database (USLCI), EXIOBASE and CML's database of impact assessment factors (CML-IA). Among these, the most popular in geothermal energy is Ecoinvent, widely recognized as the most comprehensive and complete database for the implementation of environmental life cycle assessment. At the same time, attention should be paid to the development of LCA research in Europe. The European Reference Life Cycle Data System (ELCD) may be an equally popular solution as Ecoinvent in the near future. Due to the small number of LCA studies in the field of geothermal energy, it is difficult to state clearly which of the databases is the best for use. It is worth noting, that it is not necessary to choose one base, which confirms Heberle et al. [20] and Pratiwi et al. 
[25]. In the first case, the authors used Ecoinvent and Probas bases, while in the second case Ecoinvent, USLCI and Agri-BALYSE. It seems that more important than choose of database is which method will be implemented.

The commonly used impact categories include climate change, stratospheric ozone depletion, photooxidation, acidification, eutrophication, toxicity to humans and ecotoxicity [7]. More specifically, impact categories can be divided into global, regional and local. The first group includes global warming, stratospheric ozone depletion and resource consumption. The regional categories include photochemical oxidant formation, acidification, nutrient enrichment, ecotoxity, human toxity and resource consumption. The third group - local - are photochemical oxidant formation, acidification, nutrient enrichment, effects of waste heat water, ecotoxicity, human toxicity, odor, noise, resource consumption, land use and waste [30]. An example of defining impact categories is presented in Table 2.

Table 2. A simplified example of defining 4 impact categories and defining category indicators together with the characterization parameter, indicator value and end points of category [based on 30].

\begin{tabular}{|c|c|c|c|c|c|}
\hline $\begin{array}{c}\text { Impact } \\
\text { category }\end{array}$ & LCI results & $\begin{array}{c}\text { Category } \\
\text { indicator }\end{array}$ & $\begin{array}{c}\text { Parameter } \\
\text { characterization }\end{array}$ & $\begin{array}{c}\text { Indicator } \\
\text { value }\end{array}$ & $\begin{array}{c}\text { Category } \\
\text { endpoints }\end{array}$ \\
\hline $\begin{array}{c}\text { Depletion of } \\
\text { primary } \\
\text { energy } \\
\text { resources }\end{array}$ & $\begin{array}{c}\text { Extraction } \\
\text { of fossil } \\
\text { fuels } \\
\text { resources }\end{array}$ & $\begin{array}{c}\text { Energy } \\
\text { resources in } \\
\text { primary fuels }\end{array}$ & $\begin{array}{c}\text { Lower heating } \\
\text { value per unit } \\
\text { of mass }\end{array}$ & $\begin{array}{c}\text { The total } \\
\text { lower } \\
\text { calorific } \\
\text { value }\end{array}$ & Energy \\
\hline $\begin{array}{c}\text { Depletion of } \\
\text { mineral } \\
\text { resources }\end{array}$ & $\begin{array}{c}\text { Extraction } \\
\text { of resources, } \\
\text { expressed } \\
\text { using useful } \\
\text { materials }\end{array}$ & $\begin{array}{c}\text { Extraction } \\
\text { of ore material }\end{array}$ & $\begin{array}{c}\text { Current material } \\
\text { extraction }\end{array}$ & $\begin{array}{c}\text { The total } \\
\text { mass of } \\
\text { material } \\
\text { used from } \\
\text { the ore }\end{array}$ & $\begin{array}{c}\text { Availability } \\
\text { of resources }\end{array}$ \\
\hline $\begin{array}{c}\text { Climate } \\
\text { change }\end{array}$ & $\begin{array}{c}\text { Greenhouse } \\
\text { gas } \\
\text { emissions }\end{array}$ & $\begin{array}{c}\text { Increasing the } \\
\text { intensity of } \\
\text { infrared } \\
\text { radiation }\end{array}$ & $\begin{array}{c}\text { Global warming } \\
\text { potential } \\
\text { (i.e. GWP100) }\end{array}$ & $\begin{array}{c}\text { A kilogram } \\
\text { equivalent } \\
\text { to CO }{ }_{2}\end{array}$ & $\begin{array}{c}\text { Lost years } \\
\text { of life }\end{array}$ \\
\hline $\begin{array}{c}\text { Destruction } \\
\text { of } \\
\text { stratospheric } \\
\text { ozone }\end{array}$ & $\begin{array}{c}\text { Emission of } \\
\text { gases } \\
\text { destroying } \\
\text { the ozone } \\
\text { layer }\end{array}$ & $\begin{array}{c}\text { Increases the } \\
\text { stratosphericity } \\
\text { of the ozone } \\
\text { hole }\end{array}$ & $\begin{array}{c}\text { Ozone depletion } \\
\text { potential (ODP) }\end{array}$ & $\begin{array}{c}\text { Kilograms } \\
\text { of } \\
\text { equivalent } \\
\text { CFC-11 }\end{array}$ & of illness \\
\hline
\end{tabular}

\section{Geothermal energy sector in the world}

The development of renewable energy sources in the world, causes that more and more attention should be devoted to their environmental impact in a holistic approach. How big is the potential of geothermal energy shows the data published periodically during World Geothermal Congresses, which indicate that year-on-year the installed capacity in geothermal sector increases.

In the case of geothermal power plants, it was noted that in 1995 the total installed capacity was $6832 \mathrm{MWe}$, while twenty years later (2015) it was almost $12635 \mathrm{MWe}$ (Fig. 2 ), which is an increase of $185 \%$. In the case of electricity production, it was a growth form $136926 \mathrm{TJ} / \mathrm{yr}$ in 1995 to $264776 \mathrm{TJ} / \mathrm{yr}$ in 2015 (193\%). In addition, it is estimated that in 2020, 21443 MWe will be achieved [31]. Among the countries in which installed capacity grew the most in the last five years, Kenya stands out - an increase of 392 MWe (194\%), the USA - 352 MWe (11\%) and Turkey - 306 MWe (336\%). In addition, Germany should be 
distinguished as a percentage increase in relation to the installed capacity in $2010-280 \%$ $(20 \mathrm{MWe})[31,32]$. The dynamics of the geothermal sector in Europe shows that in 2017, installed capacity in 117 geothermal power plants amounted to $2800 \mathrm{MWe}$ (16 power plants with a total capacity of $22 \mathrm{MWe}$ were put into operation in 2017). It is worth noting that there are another 30 projects under implementation, mainly in Turkey, France, Hungary, Germany, the UK, Iceland, Croatia and Belgium. Moreover, works are in progress on 276 new projects [33].

In the opposition to the electricity production, direct use of geothermal energy is possible on a much larger scale, which results from the available geothermal resources, determined primarily by the temperature of the geothermal water at the outflow. World data indicates strong increases in installed capacity and thermal energy production in the years 1995-2015. In the case of installed capacity, it was a growth from 8664 MWth in 1995 to 70885 MWth in 2015 (818\%). In the case of thermal energy production, it was respectively $112441 \mathrm{TJ} / \mathrm{yr}$ and $592638 \mathrm{TJ} / \mathrm{yr}$, which is an increase in annual production of 527\% [34]. The largest share of installed capacity belongs to heat pumps (55.15\%) and to bathing and swimming $(20.18 \%)$. However the third result belong to district heating (14.96\%).

Analyzing the data above and trends on the energy market, further growth resulting primarily from the development of the use of geothermal energy for agricultural purposes (greenhouse heating), should be expected (in Europe - 10\% per year). In addition, according to EGEC data from 2017 [33], 294 geothermal heat plants with a total capacity of 4.9 GWth was operating in Europe. Only in 2017, nine geothermal heat plants with a total capacity of 75 MWth (France, Italy, the Netherlands) were launched. In addition, 35 new projects are currently being under realization.

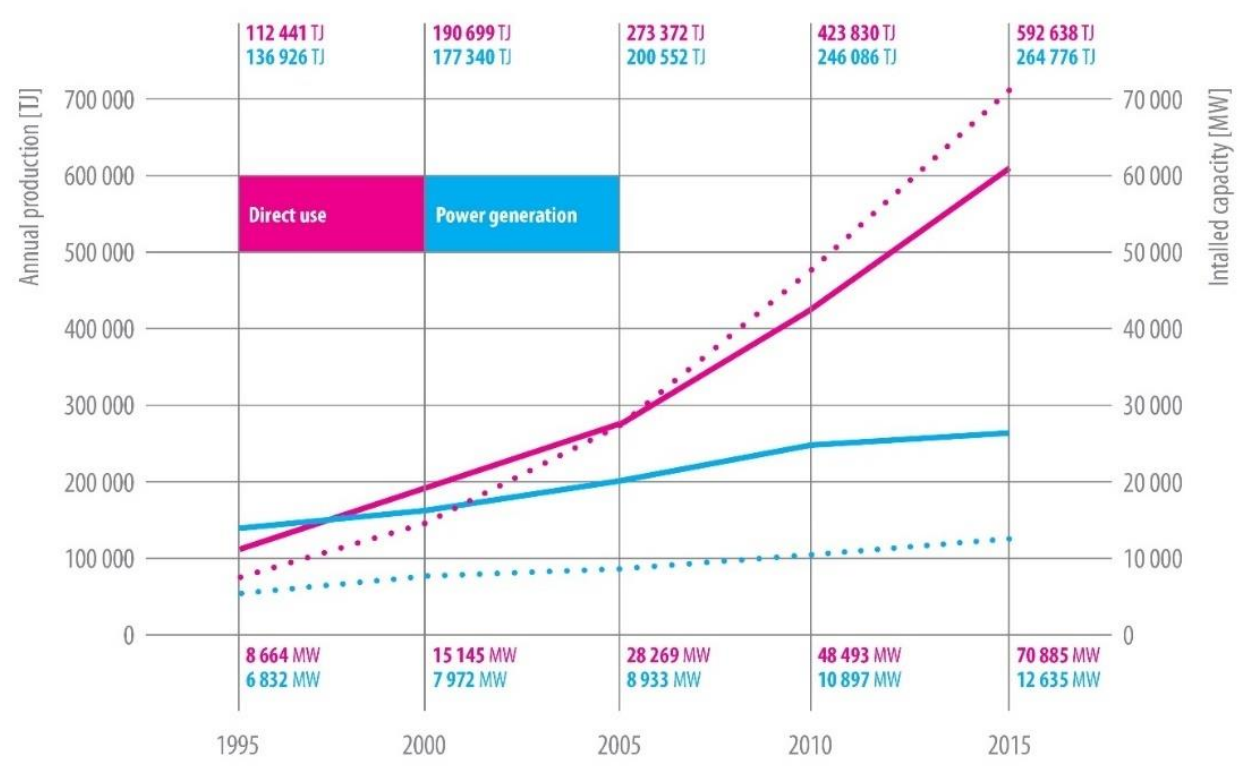

Fig. 2. Geothermal power generation and direct use in 1995-2015 (based on [31, 34] - modified). 


\section{Summary and conclusions}

Modern energy, based more and more on the use of renewable energy sources, aims to reduce emissions of pollutants into the environment. However, actions aimed at protecting the environment are mainly focused on the work stage of power/heat plants and do not take into account the impact on the environment throughout the entire life cycle. Such an approach may turn out to be short-sighted, hence the need to implement methods and use of tools that will provide a precise answer to the question about the impact of individual energy projects on the environment.

The analysis of the literature data indicates that various tools (methodologies) are used in the conduct of environmental life cycle assessment in geothermal energy. The situation is similar in the case of databases. What is interesting, the ILCD method promoted by the European Commission is not dominant in previously published works. A similar freedom of choice takes place when the impact category is determined. In result, the surveys that have been thoroughly verified are very difficult to compare in a reliable way.

Considering the above, the more justified it seems to use the environmental life cycle assessment not only in geothermal energy, but energy in general. In another way, we will not be able to answer the question to what extent individual technologies of electricity or heat production affect the natural environment. At the same time, it should be remembered that LCA is not a "negative" method, but a tool that seeks to answer the question of how to improve products/processes and minimize their negative impact on the environment.

The paper has been prepared under the AGH-UST statutory research grant No. 11.11.140.031.

\section{References}

1. M. Kaczmarczyk, E3S Web of Conferences 44, 00062 (2018)

2. M. Kaczmarczyk, Technika Poszukiwań Geologicznych. Geotermia, Zrównoważony Rozwój, 2 (2018)

3. P. Bayer, L. Rybach, P. Blum, R. Brauchler, Renewable and Sustainable Energy Reviews, 26 (2013)

4. K. Menberg, P. Blum, S. Pfister, L. Rybach, P. Bayer, Life cycle assessment of geothermal power generation (European Geothermal Congress, 2016)

5. PN-EN ISO 14040-06, Zarządzanie środowiskowe. Ocena cyklu życia. Zasady i struktura (2009)

6. PN-EN ISO 14044-06, Zarządzanie środowiskowe. Ocena cyklu życia. Wymagania i wytyczne (2009)

7. PKN-ISO/TR 14047, Zarządzanie środowiskowe. Ocena wpływu cyklu życia. Przykłady stosowania ISO 14043 (2006)

8. ISO/TS 14048, Zarządzanie środowiskowe. Ocena cyklu życia. Format dokumentowania danych (2003)

9. PN-EN ISO 14001, Systemy zarządzania środowiskowego. Wymagania i wytyczne stosowania (2016)

10. G. Rebitzer, T. Ekvall, R. Frischknecht, D. Hunkelerd, G. Norrise, T. Rydbergf, W. P. Schmidtg, S. Suhh, B. P. Weidemai, D. W. Penningtonf, Life cycle assessment. Part 1: Framework, goal and scope definition, inventory analysis, and applications (Environmental International, 30, 2004) 
11. K. Grzesik, Inżynieria Środowiska 11, 1 (2006)

12. Z. Kowalski, J. Kulczycka, M. Góralczyk, Ekologiczna ocena cyklu życia procesów wytwórczych (2007)

13. R. Dąbrowski, M. Dzikuć, PAK, 58 (2012)

14. J. Kulczycka, M. Góralczyk, K. Koneczny, P. Przewrocki, A. Wąsik, Ekologiczna ocena cyklu życia (LCA) nowa technika zarządzania środowiskowego (2001)

15. S. Frick, M. Kaltschmitt, G. Schroeder, Energy, 35 (2010)

16. C. Chiavetta, F. Tinti, A. Bonoli, Procedia Engineering, 21 (2011)

17. M. Lacirignola, I. Blanc, Renewable Energy, 50 (2013)

18. A. Nitkiewicz, R. Sekret, Energy Conversion and Management, 87 (2014)

19. E. Buonocore, L. Vanoli, A. Carotenuto, S. Ulgiati, Energy, 86 (2015)

20. F. Heberle, C. Schifflechner, D. Bruggemann, Geothermics, 64 (2016)

21. I. Bartolozzi, F. Rizzi, M. Frey, Renewable and Sustainable Energy Reviews, 80 (2017)

22. O. Hanbury, V. R. Vasquez, Renewable Energy, 115 (2017)

23. J. I. Martinez-Corona, T. Gibon, E. G. Hertwich, R. Parra-Saldivar, Journal of Cleaner Production, 142 (2017)

24. C. Tomasini-Montenegro, E. Santoyo-Castelazo, H. Gujba, R. J. Romero, E. Santoyo, Applied Thermal Engineering, 114 (2017)

25. A. Pratiwi, G. Ravier, A. Genter, Geothermics, 75 (2018)

26. Ministry of Housing, Spatial Planning and the Environment, Eco-indicator 99. Manual for Designers. A damage oriented method for Life Cycle Impact Assessment (2000)

27. J. B. Guinée, M. Gorrée, R. Heijungs, G. Huppes, R. Kleijn, A. Koning, L. Oers, A. Wegener Sleeswijk, S. Suh, H. A. Udo de Haes, H. Bruijn, R. Duin, M. A. J. Huijbregts, Handbook on life cycle assessment. Operational guide to the ISO standards. I: LCA in perspective. IIa: Guide. IIb: Operational annex. III: Scientific background. Kluwer Academic Publishers (2002)

28. M. A. Wolf, R. Pant, K. Chomkhamsri, S. Sala, D. Pennington, The International Reference Life Cycle Data System (ILCD) Handbook. Towards more sustainable production and consumption for a resource efficient Europe (2012)

29. M. Bogacka, K. Pikon, M. Landrat, Waste Management, 70 (2017)

30. H. K. Stranddorf, L. Hoffmann, A. Schmidt, Environmental News, 78 (2005)

31. R. Bertani, Geothermal Power Generation in the World 2010-2014 Update Report (Proceedings World Geothermal Congress, 2015)

32. B. Matek, 2015 Annual U.S. \& Global Geothermal Power Production Report (2015)

33. P. Dumas, T. Garabetian, V. Pinzuti, C. Marchitelli, 2017 EGEC Geothermal Market Report. Key Findings (2018)

34. J. W. Lund, T. L. Boyd, Geotermics, 60 (2016) 